\title{
Male Same-Sex Relations in Modern China: Language, Media Representation, and Law, 1900-1949
}

Wenqing Kang

Cleveland State University, w.kang@csuohio.edu

Follow this and additional works at: https://engagedscholarship.csuohio.edu/clhist_facpub

Part of the Asian History Commons, Chinese Studies Commons, History of Gender Commons, and the Lesbian, Gay, Bisexual, and Transgender Studies Commons

How does access to this work benefit you? Let us know!

\section{Publisher's Statement}

Copyright Duke University Press. Article first published in Positions, 18(2), 489-510.

doi:10.1215/10679847-2010-011 http://positions.dukejournals.org/content/18/2/489.abstract

\section{Original Citation}

Wenqing, K. (2010). Male Same-Sex Relations in Modern China: Language, Media Representation, and Law, 1900-1949. Positions, 18(2), 489-510. doi:10.1215/10679847-2010-011

\section{Repository Citation}

Kang, Wenqing, "Male Same-Sex Relations in Modern China: Language, Media Representation, and Law, 1900-1949" (2010). History Faculty Publications. 102.

https://engagedscholarship.csuohio.edu/clhist_facpub/102

This Article is brought to you for free and open access by the History Department at EngagedScholarship@CSU. It has been accepted for inclusion in History Faculty Publications by an authorized administrator of EngagedScholarship@CSU. For more information, please contact library.es@csuohio.edu. 


\section{Male Same-Sex Relations in Modern China: \\ Language, Media Representation, and Law, 1900-1949}

Wenqing Kang

In China during the first half of the twentieth century, the issue of male same-sex relations appeared in venues such as Peking Opera, literary works, sexological writings, and, most prominently, tabloid newspapers. In those various social locations, which were either new (sexology, tabloids) or in the process of being transformed (opera, literature), urban citizens argued about the importance of a modernized understanding of gender and sex in order to become a strong nation.

With an increasing number of works on women's history in China, gender has proven to be an indispensable analytical category in the study of Chinese history, but masculinities and male same-sex relations are rarely addressed as a way of broadening our understanding of modern China. The limited studies of same-sex relations in twentieth-century China tend to focus on how Western sexology was viewed in China. For example, in Sex, Culture 
and Modernity in China, based on published sexual manuals, Frank Dikötter argues that the Chinese modernizing elites of the Republican period did not adopt the Western concept of sexuality and still understood "homosexuality" as "an acquired aberration or a temporary disease which should be eliminated," and supported his argument with the fact that "the criminal code in China, to this day, does not have a specific law recognizing or prohibiting homosexuality." However, in The Emerging Lesbian: Female Same-Sex Desire in Modern China, Tze-lan D. Sang contends that "the medicalization of same-sex relations that began during that period indeed represented a dramatic departure from late-imperial literary depiction of such relations in terms of vocabulary and truth claims."2 Both Dikötter and Sang rely on sexological writings of the early twentieth century, but the two scholars have reached very different conclusions. Sang's argument might be valid for female same-sex desire, but not for male same-sex relations. The problem is that neither of the two scholars has taken into consideration the internal contradictions within the Chinese indigenous understanding of male same-sex relations as well as those within the Western modern homosexual/ heterosexual definition.

In this essay, instead of asking the old question of whether acts became identities with the arrival of modern Western sexology in China in the early twentieth century, I will discuss the tension in the Chinese indigenous terminology for male same-sex relations, which was quite like what Eve Sedgwick describes about the Western modern homosexual/heterosexual definition. Rather than focusing on medical and sexological writing, I analyze major urban tabloid newspapers such as Shanghai’s Jingbao (晶报, Crystal) and Tianjin's Tianfengbao (天风报, Heavenly Wind), as well as other journalistic writings and legal discourses. I argue that the Western sexological concept of homosexuality was accepted and incorporated in early-twentiethcentury China because it was similar to the local understanding of male same-sex relations. I also demonstrate how new meanings were produced in the process of epistemological encounters under the historical context of semicolonial China. Finally, I answer the question of why the Republican state legal apparatus had no clear stipulations on sex between men. 


\section{Encounters between Indigenous Chinese Discourse and Modern Western Sexology}

In Epistemology of the Closet, Sedgwick points out that the modern Western homo/heterosexual definition is internally incoherent and mutually contradictory. ${ }^{3}$ On the one hand, homosexuality is defined as a special issue for a minority group of people, and on the other hand, it is assumed that homosexuality could happen to anyone. Additionally, homosexuals are considered to embody the essential position of their own gender, whereas on another parallel model, they are understood as gender transitive. ${ }^{4}$

Those tensions are also found in Chinese terminology for male samesex relations. The term pi (癖, obsession), which was used to characterize men who enjoyed sex with other men, could also suggest a pathological mental state. ${ }^{5}$ The idea, on the one hand, implied that men who had this kind of obsession were a special type of person, and on the other hand, presumed that the obsession could happen to anyone. The Chinese term renyao (人妖, freak, fairy) could refer to an impersonator of a member of the opposite sex. When used to refer to men who have sex with other men, the term at once insisted that a person was male and that he had become female due to his sexual behavior. Moreover, in classical Chinese writings, renyao was regarded as an inauspicious sign for the dynasty. The term Duanxiu (断袖, referring to the story that an emperor in ancient China cut his own sleeve, which his male favorite was sleeping on, in order not to wake the lover up when he got of bed himself) suggested the sexual relationship between emperors and their male favorites, a relationship that was stigmatized in the belief that male favorites would interfere in politics and cause problems to the state. In the semicolonial context of twentieth-century China, the connotation of renyao, along with the negative understanding of male favorites and the idea of $p i$ as pathological obsession, were employed to represent the sickness of the nation and to condemn men who had sex with other men as the cause of political chaos and national misfortune of the time.

In classical Chinese medical and literary writings, $p i$ was on the one hand understood as "a pathological fondness for something." logical aspect of this idea suggested that pi could only happen to a certain group of people, and was not a normative situation. On the other hand, 
$p i$ "also comes to denote the individual proclivities inherent in all human nature." Judith Zeitlin points out that "this paradoxical view of obsession as at once pathological and normative helps account for the peculiar range of behavior associated with it and for contradictory interpretations assigned to it." ${ }^{8}$ The contradictory interpretations assigned to pi (obsession) as both pathological and normative also became the conceptual framework for sex between men.

The pathological interpretation of pi (obsession) concurs with what Sedgwick calls the minoritizing view of the homo/heterosexual definition, which can also be a pathologizing view, while the understanding of pi (obsession) as normative corresponds to the universalizing view that Sedgwick describes. When Western modern sexology was introduced to China in the first half of the twentieth century, the Chinese understanding of male same-sex relations as pi (obsession) was very much alive, as evidenced in the writings of the time. It was precisely because of the similarity between the two sets of understandings that Western modern sexology could gain a footing in China, as the following example suggests.

From the early I920s, when the Chinese translation of the Western term “homosexuality,” tongxinglian'ai (同性恋爱) or tongxing'ai (同性爱), first appeared, it was not only employed to introduce Western sexological thought to a Chinese audience, but also was used as an alternative term to the indigenous Chinese expressions by writers who wanted to apply the Western idea to the Chinese context of male same-sex relations.

One of the examples of the application was an entry called tongxinglian'ai (同性恋爱, homosexuality or same-sex love) appearing in Shanghai Tidbits (上海鳞爪, Shanghai linzhao), a collection of social commentary in a notation book (笔记, biji) style, first published in I933. In this entry, the writer $\mathrm{Yu}$ Muxia (郁慕侠) first provided a rudimentary explanation of tongxinglian'ai by drawing an analogy between the meaning of the Western term and what he perceived as the common heterosexual relationship. ${ }^{9}$ He then familiarized the reader with the idea of homosexuality by relating it to Chinese expressions, jijian (鸡奸, sodomy or buggery) $)^{10}$ and mojing (磨镜, mirror rubbing, referring to female same-sex relations).${ }^{11}$ Furthermore, he introduced the new idea of “sexual perversion” (xingyu shang de biantai, 性欲上的变态) to the reader. Clearly, in the process of this translation, Yu had no difficulties 
in fusing Chinese indigenous thought on same-sex relations with Western sexology. He made the new term even more familiar to the reader by invoking further Chinese expressions, as follows:

People say, "In Shanghai, sexual desire has been running rampant; and consequently, sexual perversion has occurred. That is why in the hinterland, [perversion] is rarely seen.” In my opinion, longyangjun (龙阳君, the name of a male favorite in ancient history) and duanxiupi (断袖癖) has existed since antiquity. We should not simply blame [the perversion] on the particular place that is Shanghai; it is only by comparison that those things happen more frequently in Shanghai [than in other places]. ${ }^{12}$

Here, Yu simply used duanxiupi, the obsession of the cut sleeve, as the ancient version of tongxinglian'ai. Apparently, the connection between the two concepts was that both of them framed same-sex relations within a minoritizing view as a diseased condition. For the writer, the connection was so obvious that he did not even feel compelled to explain it. In the second part of the entry, the writer also revealed his universalizing view of tongxinglian'ai:

Besides, in the late Qing and early Republican period, the vogue of "wan xianggong" (玩相公, play with xianggong: male actor/prostitute) and "xia xiaodan” (狎小旦, being intimate with young dan actors: male actors who played female roles) was flourishing in the North. The patrons claimed that they opened up an alternative path [to female prostitution], and the hosts also admitted that they were running a kind of ugly business. Last year, male prostitutes Zhong Xueqin and Luo Meiren appeared in Shanghai, and they were exactly this kind of Northern xianggong. But it should not be called tongxinglian'ai, and it could only be said that the enthusiasm for sex led [the patrons] to play at their will. The concession authority has strictly forbidden male prostitution for a long time because it is harmful to social morals. So they do not dare to run their business in the open. Most of them are like unlicensed female prostitutes, dealing secretly. ${ }^{13}$

In this passage, $\mathrm{Yu}$ first declared that Shanghai male prostitutes were the same as the northern opera actors/male prostitutes called xianggong. But he insisted that the situation was not one of tongxinglian'ai; as he wrote, "the 
enthusiasm for sex led [the patrons] to play at their will." They visited male prostitutes simply because they wanted to have sex. One of the unstated assumptions was that those patrons might also visit female prostitutes, and that their interest in sex with men was not different from their interest in women. This aspect of understanding precisely revealed the universalizing view that homosexual sex was possible for anyone. The two sets of contradictory conceptualizations thus established a homology between an indigenous understanding of sex between men and the Western concept of homosexuality. In other words, the homology facilitated the introduction of the new idea of homosexuality to China.

One group of people labeled as renyao were Peking opera dan actors, male actors who played female roles. A 1932 article in the Tianjin tabloid newspaper Tianfengbao (天风报, Heavenly Wind) was a good example:

A certain amateur dan actor (huadan piaoyou mou, 花旦票友某), who was a southerner growing up in the north, has an elegant and beautiful name. He was born with [feminine] beauty (tianshenglizhi, 天生丽质), and resembles a cultivated lady (maoruoguixiu, 貌若闺秀). ${ }^{14} \mathrm{He}$ has had sexual relations with more than twenty handsome young men (mianshou, 面首). According to those who have been intimate with him, despite his male body, he is equipped with feminine characteristics. In bed, he is tender and tactful, and his lasciviousness surpasses that of courtesans. All of those who have had intercourse with him are enchanted by him.

The writer then expressed frustration over the actor's gender and sexual transgression, and drew a connection between his behavior and the national crisis:

Being already forty years old and supposedly not confused anymore, I often heard about the filthy deeds of dan actors, and thought that they should not be taken literally. Now I realize that such a unique creature (youwu, 尤物 $)^{15}$ does exist. The country is on the verge of extinction because freaks and monsters are present (guozhijiangwang, biyouyaonie; 国之将亡, 必有妖萑). Such a person probably is renyao. ${ }^{16}$

The unnamed amateur dan actor was labeled as renyao, freak or fairy, obviously because he, as a man, had had sexual relations with many men. In 
addition, he had strong female traits. Thus, not only did his sexual behavior violate social norms, but his body itself also became a sign of transgression. In his comments, the writer made the unnamed actor even more worthy of condemnation by blaming people of his kind for the political crisis of the nation. Here, the thought that renyao in the form of gender confusion was an inauspicious indication of dynastic crisis was applied to the context of twentieth-century China.

Renyao, men who had sex with other men, on the one hand were considered to be expressing the essence of masculinity even as they transgressed sexual and gender norms. On the other hand, because of their sexual transgression, they were viewed as losing their masculinity, and thus occupying a gender liminal position. This conceptual incoherence correlated with the internal contradiction between gender separatism and gender transitivity in the modern homo/heterosexual definition analyzed by Sedgwick. Together with the idea of $p i$, the understanding of renyao provided a receptive discursive condition for the dissemination of the Western concept of "homosexuality."17

\section{The Model of the Emperor-Male Favorite Relationship}

Certainly, Western sexological terminology did not totally replace the indigenous Chinese understanding of male same-sex relations. From the downfall of the Qing dynasty in I9I I to the establishment of the Nationalist government led by Jiang Jieshi in 1927 , China was in political turmoil, during which warlords fought among themselves for regional power. Chinese writers were concerned about the chaotic state of the new republic. In Chinese historical writings, male same-sex relations between an emperor and his male favorite were sometimes used as a sign of weak political rule. In the I920s, some writers picked the issue of male homoerotic relations of high-ranking officials and used the tabloid newspaper Crystal (Jingbao) as a forum to vent their discontent with the warlord regime. They also used it as a sign of the government's political impotence. 


\section{Cao Kun and Li Yanqing}

The most frequently discussed case immediately after the Fall of the Qing was the liaison between Cao Kun (曹锟) and his assistant Li Yanqing (李彦青) when the two were in power. ${ }^{18}$ Cao Kun was one of the most powerful warlords from the mid-igios to the mid-ig2os. Born into a poor vendor's family in Tianjin in I862 and without much schooling, he joined the Huai Army (淮军), a division of the Qing military force, at the age of twenty and soon thereafter attended the Tianjin Military Academy. After graduation in I89o, Cao served in various places, including Korea during the I894 SinoJapanese War, and was repeatedly rewarded and promoted by the Qing government. Through most of his military career, Cao had followed Yuan Shikai (袁世凯), and by the end of the Qing dynasty in I9II, he had become a provincial commander-in-chief in Northeast China. In I9ı6, Cao became the military governor of Zhili (present-day Hebei). Commanding a welltrained division of the Beiyang Army, he was an important warlord in north China. In October 1923, his subordinates bribed members of the National Assembly into electing him as the president of the Beijing government. In November 1924, he was forced to resign from the position when two other warlords, Feng Yuxiang (冯玉祥) and Zhang Zuolin (张作霖), took over north China. ${ }^{19}$

Li Yanqing came from a poor family in Harbin and did not have much education either. As a young man, he worked as a bathhouse attendant, providing massages for customers. Cao Kun often went to Li's bathhouse when he was stationed in Northeast China as a general. Cao was very fond of $\mathrm{Li}$ and kept him as a personal servant. When Cao became president, Li took advantage of his position and began to sell government titles and interfere in political affairs. Many high-ranking officials became Li's friends and sworn brothers in order to keep their positions. ${ }^{20}$

When the topic of the Cao-Li relationship was first broached in Crystal in January 1924, the writer did not mention the names of either Cao or $\mathrm{Li}$, although most readers knew whom he was talking about. ${ }^{21}$ The article began by proposing a change of terminology. In Shanghai, male servants for Westerners and attendants in Western-style restaurants and hotels were called xizai (西崽, Western boys). According to the writer, the Chinese word 
$z a i$ in the north was another way of saying "rabbit” (tuzi, 兔子), referring to a young passive partner in male same-sex relations. ${ }^{22}$ But the relationships between Westerners and those male servants were not necessarily sexual. It was unfair, the writer said, to use this term to label those servants. What the writer proposed, however, was that catamites (luantong, 娈童) favored by a certain warlord should be named junzai (军㩄, military boys). In Chinese history, he commented, eunuchs often interfered in politics. Eunuchs were long gone, but rabbits had come to power. The writer thus implied that the relationship between the warlord and his "military boy" was sexual.

What the writer did was to put the Cao-Li liaison into a model recalling the relationship between an emperor and his male favorite. Here, male same-sex relations, despite the new form, were viewed as an old phenomenon that had always caused problems in China. In such a configuration, the Cao-Li relationship became sexualized. Equated with a eunuch, Li was also feminized. As the writer complained at the end of the article, "Everything has to have a female touch (yinqi, 阴气) in China.” This statement not only gendered $\mathrm{Li}$ as female, but also blamed the femaleness for the problem of the nation. ${ }^{23}$

What concerned those writers most was that Li took advantage of his sexual relationship with Cao to interfere in the political affairs of the nation. One popular story was that $\mathrm{Li}$ was summoned by Cao to wash his feet when Li was playing mahjong with some important officials, and had to leave the table immediately. ${ }^{24}$ Because of Li's special relationship with Cao, even the Japanese showed him respect. Many writers who did not approve of the relationship ridiculed Li's lowly background and his lack of basic schooling. In a Crystal story, Li was portrayed as so illiterate that he presumably became infuriated while reading a Japanese letter because he mistook a deferential Japanese expression (御免) for an insulting term and believed that he was being addressed as “imperial rabbit”(御兔). ${ }^{25}$

Immediately after Cao was forced to resign from his presidency and $\mathrm{Li}$ was arrested by Feng Yuxiang's army in November 1924, more satires about the two appeared in Crystal. One story described Cao as a salacious man, addicted to sex with both men and women. The reason he joined the military, stories suggested, was that he was not even a qualified fabric vendor. He often sold his fabric at a low price to women who knew his weakness and flirted with 
him. As a result, he could not make any money and had to sell his clothselling stand. ${ }^{26}$ A report on Li said that he refused to put on his clothes when he was arrested. The writer commented that this time his specialty of being a male favorite did not work. ${ }^{27} \mathrm{Li}$ was also said to have two concubines, who took his money and ran away with other men after his arrest. ${ }^{28}$

The purpose of these stories was to expose the ugly side of the two men and applaud the fact that they were finally out of power. Meanwhile, the articles revealed how these writers understood male same-sex relations at that time. By framing the Cao-Li case on the model of an emperor-male favorite relationship, those writers suggested that sex between men could be damaging to the country; yet they did not see sex between men and sex between men and women as mutually exclusive, an understanding of male same-sex relations prevailing in China well into the twentieth century.

The Cao-Li relationship was first characterized by the Crystal writers as a problem of the warlord regime, repeating a pattern in Chinese history in which eunuchs and male favorites interfered in political affairs. In such a configuration, male same-sex relations in the warlord period were conceived both as a sign of weakness on the part of the government and a threat to the strength of the nation. Years later, as shown in Heavenly Wind, Li's story was transformed into a moral warning that a man deserves death if he uses his sexual relationship with a powerful man to interfere in political affairs and benefit himself.

\section{Puyi and the Puppet State of Manchuria}

Another important political figure who had a reputation of preferring men to women was the last Qing emperor, Puyi. In I93I, the Japanese Army invaded Northeast China. On March I of the following year, they set up a puppet state of Manchuria in Changchun and brought Puyi from Tianjin to be the executive, eventually making him emperor in $1934 .{ }^{29}$ During this period, reports on Puyi and the puppet state appeared in Crystal. The writers did not clearly make the connection between Puyi's sexual preference and the Japanese colonial conquest. However, male same-sex relations, along with other forms of sexual perversion, were presented by these writers as defects of the Japanese colonizers and their collaborators. 
A commentary appeared in Crystal in August I93I, listing various cases of sexual perversion in Japan. ${ }^{30}$ The writer began the article by commenting sarcastically that "Japan claims to be a country connecting Eastern and Western civilization, and therefore strange things have occurred one after another." A man raped and killed a rich woman in an urban forest during daytime; another young man was taking peeks at naked people in a public bathhouse every night; a third was an exhibitionist, hiding in a quiet alley waiting to expose himself; and a fourth wrote several hundred indecent letters to a woman. Moreover, a juvenile delinquent was sentenced to have his penis cut off for sexual offenses. The writer portrayed Japan as a land of inexplicable sexual crimes and clearly questioned the meaning of civilization that Japan claimed to embody.

The Japanese military attack on northeast China began on September I8, I93I. Two weeks before the action, Crystal reported that Puyi's concubine Wenxiu had filed for divorce and asked for 500,ooo yuan compensation. The reason, as Wenxiu's letter to her brother revealed, was that "she was not favored once in ten years of living together (with Puyi)" (shinian xiangchu, weimeng yixing; 十年相处, 未蒙一幸). ${ }^{31}$ In this report, the writer explained that Puyi usually enjoyed eating and sleeping with little eunuchs, and attributed Puyi's sexual preference to the habit of northerners. Situating himself as a southerner, the writer claimed that northern men were capable of having sex with other men, but were not good at having sex with women. Thus, he figured, the problem of "Mr. Puyi" was hard to cure. ${ }^{32}$

In January 1932, less than two months before the puppet state was established, a report said that the Japanese army had been preparing a farce of restoration. The report described the deterioration of Puyi's financial situation at the same moment. He began to sell antiques that he had taken away from the imperial court to make ends meet. The report emphasized that his two favorite pastimes were singing Peking Opera and collecting goldfish. Apparently, he especially enjoyed singing arias of characters of dethroned emperors. After his concubine Wenxiu left, Puyi got along well with his first wife, the former empress. But the writer did not forget to mention that the former emperor still spent most of his time with young eunuchs, and it was said that the relationship was sexual. ${ }^{33}$

In the above two reports, Puyi's sexual preference for men, along with his 
financial insolvency and his indulgence in Peking opera, were clearly represented as the weakness of the former Chinese emperor, and that of China as a nation, which made the Japanese invasion possible. As the colonial crisis was deepening in northeast China, male same-sex relations were presented as evidence of the corrupt and decadent lives of the collaborators. ${ }^{34}$

These articles marked the apogee of reporting on the sexual chaos of the puppet state. In the subsequent years, news of Puyi's same-sex relations continued to appear periodically until Japan fully invaded China in 1937, when the media focus on the Japanese invasion turned away from the Northeast to the whole country. ${ }^{35}$ In all of these reports, Puyi's sexual preference was understood through indigenous categories of emperor-male favorite relations, which historically could function as a sign of dynastic decline. In the context of Japanese colonization, the relationship became the evidence of a weakness of Chinese masculinity, which caused a growing crisis of the nation. Meanwhile, the Western sexological idea of perversion was also employed by the writers to ridicule the self-proclaimed enlightened Japanese civilization.

\section{Why the Republican State Had No Legal Stipulations on Sex between Men}

In the first half of the twentieth century, tabloids were not only an arena in which new meanings of male same-sex relations were produced in semicolonial China, but also provided a forum to discuss legal issues related to same-sex relations. In 1925, in Wuxi, a county very close to Shanghai, a woman named Liu Jingzhu was sentenced to three years and six months' imprisonment by the head of the county for the crime of "seduction with consent” (heyou, 和诱). According to a Crystal report, a previous judge had dropped the case because the other woman involved, Huang Xiaomei, who was younger than the accused, did not admit that any "homosexual relations” (tongxinglian'ai zhi guanxi, 同性恋爱之关系) had occurred. ${ }^{36}$ The judge also believed that this kind of personal issue was beyond the realm of law and should be treated leniently. However, the Wuxi county head deemed the issue socially important and insisted on pursuing the case. Unable to establish any evidence of "homosexuality" (tongxinglian'ai, 
同性恋爱) even after interrogating the two women separately, the county head first employed the term “seduction” (youguai, 诱拐). When Huang confessed that she had traveled with Liu voluntarily, instead of exonerating Liu, the official charged her with committing "seduction with consent." Liu later appealed to the Jiangsu provincial superior court. In the new trial, Huang finally testified that Liu had seduced her into sleeping together and had inserted a dildo inside her body. The superior court judge therefore denied the appeal and maintained the earlier verdict. In the rejection letter, the judge invented a new legal term and named Liu's offense "illicit sex by rubbing” (cajian, 擦奸). ${ }^{37}$

According to Philip Huang's study of legal practice in Qing and Republican China, during the first twenty years after the fall of the Qing, the new Republican government still used the I9I I Qing Code that had been revised right before the end of the dynasty. The government further adopted the criminal code that had been drafted but not yet promulgated in the last days of the Qing period. But the civil stipulations in the Qing Code "in fact covered quite well most of the areas of frequent disputes among the populace." 38 The new state civil code of the Guomindang (Republican Party) was not promulgated until I929-30, while the criminal code was not issued until I928, and was later revised in $1935 \cdot{ }^{39}$ Therefore, Liu's sentence, which was handed down in 1925, would have been based on the Qing code. As Huang argues, the important difference between the Qing code and the Guomindang civil and criminal codes was the understanding of the position of women, which manifested itself in the use of the Chinese word he (和). In the Qing code, as Huang points out, "When referring to the woman, the he meant to consent to." However, "When applied to the man, it meant literally doing something to a woman with her consent." Thus, heyou meant "seducing a woman with her consent." This usage was gender-specific. It was the man that did the you, or seduction. "He did not he; the woman was the one who he-ed." Therefore, "what these he categories reveal, in fact, is the way Qing law saw the nature of choice or will exercised by the woman." 40 As Huang explains, "For the Qing code, the man was the active agent in all of these offenses, and the woman the passive entity, though not a will-less one. $\mathrm{He}$, the law assumed, was the leader (weishou, 为首) and she the follower (weicong, 为从). She had a measure of choice, to be sure, but it was limited 
to what we might term a 'passive agency': she could resist or she could submit." ${ }^{41}$ In the 1928 Guomindang criminal code, however, all the he terms disappeared except where minors were involved. Instead, an adult woman was considered an independent agent and "could not be victim of seduction, only of forcible abduction." 42

Therefore, according to the legal code in effect in 1925, only men could commit the crime of "seduction with consent." The sentence that the woman Liu received from the county head of Wuxi apparently lacked a legal basis, and the case stirred a heated discussion among Crystal contributors on legal issues related to same-sex relations.

After the parents of the younger woman, Huang, brought the older woman, Liu, to court, Crystal revealed the case to the public and followed its development. Commentary on the case became a discussion of the law on seduction and rape and the philological meaning of jian (奸, illicit sex). In the initial report, the Crystal writer posed a question to lawyers as to whether the crime of seduction with consent could be established between women. A response was later published in Crystal, which not only answered the question but also provided a definition of rape (qiangjian, 强奸). ${ }^{43}$ According to the writer, the law did not limit the crime of heyou to men. As he explained, based on article 394 of the criminal code (xingfa, 刑法), both men and women could commit the crime of seduction with consent, and victims also could be either male or female. A woman could even be held accountable for a rape if she helped a man to rape another woman. However, a prerequisite for rape was the contact between male and female genitalia (yinyang liangwu zhi jiechu, 阴阳两物之接触), thus the principal criminal in the end was male. Forced sex between men was called sodomy (jijian, 鸡奸), and that between women was mirror rubbing (mojing, 磨镜). Both belonged to the category of crimes of forced lewd acts (qiangzhi weixie zhi fanxing, 强制猥琶之犯行), but could not be counted as rape. Apparently, by providing his interpretation of "seduction with consent," and even invoking the rare scenario in which a woman could be held accountable for rape, the writer intended to side with the Wuxi county head and defend his verdict.

The law that the above writer referred to was the criminal code written in the last days of the Qing period, which was adopted by the new Republican government with a minor revision in I9I2, and was ostensibly in effect 
in 1925 . But other writers had different interpretations of the code regarding female same-sex relations. An example is a book entitled On Homosexuality (Tongxinglian'ai lun, 同性恋爱论), published by Shanghai East Asia Bookstore (Shanghai dongya shuju, 上海东亚书局) in I925. There is uncertainty as to the origins of the book. ${ }^{44}$ It was a translation from a Japanese work, which was very likely itself a translation from a Western language. But the Chinese translator, Wu Ruigong (吴瑞公), supplemented the content with relevant information on China. What he intended was not to defend the legality of same-sex relations. In fact, he urged the Republican legislature to establish laws to criminalize same-sex relations. According to $\mathrm{Wu}$, the I9I2 New Criminal Code Temporarily in Force (zanxing xinxinglü, 暂行新刑律), which was modeled on Japanese law, did not criminalize "female homosexuality” (nüxingjian zhi tongxinglian'ai, 女性间之同性恋爱) at all. ${ }^{45}$ In Wu's interpretation of the criminal code, only males could be held accountable for lewd acts. Also, the only articles that could be used to criminalize “male homosexuality (nanxingjian zhi tongxinglian'ai, 男性间之同性恋爱)” were those concerning lewd acts. Furthermore, as he made clear, sex between men was not a considered a crime unless one party was forced or under twelve years old. ${ }^{46}$

In the Crystal report on the final verdict of the Liu-Huang case, the writer questioned the legal basis of the term "illicit sex by rubbing." 47 Two days later, the chief editor of Crystal, Zhang Danweng, wrote a commentary on the newly invented term. ${ }^{48}$ Zhang explained the semantic connotation of the Chinese term “jian,” providing further information on the indigenous understanding of same-sex relations in China in the I92os. As he said, the word “jian” conveyed a meaning of “luan” (乱, disorder, or illicit sex), referring to illicit sex between a woman and a man who was not her husband that would derail the patrilineal line of the husband's family. Following this understanding, Zhang insisted that sexual intercourse between two men (liangnan xiangjian, 两男相奸) could not be called jian. A category such as “jijian” (sodomy), he said, had never appeared in the Chinese law from the Han to the Tang dynasty. The early cases were established and adjudicated according to the statute that a man would be punished if he "inserts foul material into the mouth of another person" (yi huiwu ru renkou, 以秽物入人口). 49 Zhang did not believe that the expression "mirror rubbing" was an inde- 
cent term in classical Chinese and thought it unnecessary to invent the term "illicit sex by rubbing," which was even more confusing. In his opinion, the issue of female same-sex relations had never been mentioned in Chinese law, and thus it should not be considered a crime. The three years and six months in prison perhaps could be considered as a punishment for seduction.

Central to the whole discussion was whether same-sex relations, female or male, could be considered as jian, which by semantic definition referred to illicit sex between a male and a female. Zhang was correct when saying that early cases of sex between men were treated as "inserting foul material into the mouth of another person.” As Matthew Sommer clearly explains in his study on sex and law in the Qing period, from the Jiajing reign (1522-67) of the Ming dynasty on, a supplementary set of "statutes applied by analogy” (biyinlü, 比引律) was added into the Ming code. Under one such statute, "Whoever inserts his penis into another man's anus for lascivious play ( jiang shenjing fangru ren fenmen nei yinxi, 将肾茎放入人粪门内淫戏), shall receive IоO blows of the heavy bamboo, in application by analogy of the statute 'pouring foul material into the mouth of another person' (hui wu guan ru ren kou, 秽物灌入人口)." ${ }^{50}$ However, as Sommer points out, "the statute quoted above never mentions jian at all, let alone the Qing legal term for sodomy, jijian." ${ }^{1}$

What Zhang Danweng was unaware of, or ignored, in his commentary was what Sommer calls "the assimilation of sodomy to illicit sex" in the high Qing period. ${ }^{52}$ In 1734 , a substatute was added in the illicit sex (jian, 奸) chapter of the Qing code. This substatute had a clear proscription against sex between men, forced or consensual. The category of sexual offenses between men was thus modeled after the preexisting classification of illicit sex between men and women. Moreover, "Consensual sex with a person over twelve sui of either sex was punished according to the substatute on 'soldiers or civilians engaged in illicit sex' (jun min xiang jian, 军民相奸), by Ioo blows of the heavy bamboo and one month in the cangue." ${ }^{3}$ Finally, "any sodomy offense not covered in the code was judged by precise analogy to the corresponding heterosexual offense." ${ }^{4}$ Therefore, based on the legal concept of "statutes applied by analogy," after I734, the Qing code had established a system to criminalize sex between men. 
However, the legal history of China regarding sex between men was a more complicated story than a linear progression from lenience to severity. During the Republican era, statutes written explicitly on male same-sex relations such as those in the I734 Qing code disappeared in the law, and such relations were not legally criminalized. ${ }^{55}$ The late Qing criminal code, drafted in 1907 , invalidated the former legal practice of "statutes applied by analogy," and stipulated clearly that "no one should be criminalized for any conduct that was not officially written as prohibited in the law." 56 This stipulation limited the court's ability to interpret the law freely and apply statutes as they saw fit. As a result, sex between men could no longer be construed as illegal because there was no specific law criminalizing male same-sex relations in the adopted I9I2 criminal code.

Through the discussion of the term "jian," these newspaper reports clearly showed the connection between male same-sex relations and female same-sex relations. The reports revealed not only the social attitude toward the issue of sex between men but also how the issue of sex between women was understood and used by people of different persuasions. For people such as the writer of the initial report, the first judge of the case, and even the "victim" Huang herself at the beginning of the trial, sex between women, as a personal issue, should not be discussed in public, nor should it be used to prosecute anyone. However, for Huang's parents, the head of Wuxi county, and the judge of the Jiangsu Superior Court in the appeals trial, sex between women had to be talked about explicitly even at the cost of inventing new legal terms and eventually could be used as evidence to punish women such as Liu who were sexually transgressive. This attitude betrayed social anxiety about the changing gender order at the time; the punishment of Liu was an effort to appease the fear. What also became clear from this conversation were understandings and attitudes toward same-sex relations. During this period, although same-sex relations between men or between women were not considered socially serious insofar as they would not interrupt a patriline, the issue could be used to the disadvantage of women who were not confined by conventional gender roles. 


\section{Conclusion}

In the first half of the twentieth century, indigenous thought provided a condition for the spread of modern sexology, which, in the context of an unequal power relationship between China and the West, eventually acquired its legitimacy in the name of science. It was precisely the encounter between the two forms of knowledge that not only recycled and reinforced some old ideas, but also produced some new meanings in the semicolonial context. Indigenous understanding of male same-sex relations was supposedly updated to the standard of modern Western knowledge in order to strengthen the nation, but in fact the two shared a similar conceptual inconsistency. Moreover, the age-old framework of the emperor-male favorite relationship was still used to denounce warlord and colonial aggression. It is important to note that while writers condemned male same-sex relations, the condemnation did not always use the sexological model. Many writers did not simply condemn the sexual aspect of the relation, but paid more attention to the gender and political aspects. They were more concerned with the proper gender behavior and the image of the nation than sex itself.

The discussion of the meaning of "jian" occasioned by the legal case of female same-sex relations revealed the Chinese indigenous understanding of what constituted illicit sex and the meaning of same-sex relations. Neither sex between men nor sex between women was considered as serious as illicit sex between a man and a woman because they would not result in the disruption of the patriline. But this did not mean that same-sex relations were socially or legally accepted. The absence of the legal regulation on same-sex relations during the Republican era was not so much intentional as an unanticipated consequence of the late Qing elite's effort to modernize Chinese law. Ironically, while both Chinese sexologists and tabloid writers joined the chorus pathologizing and demonizing male same-sex relations, official legal regulation remained silent on the issue. Nonetheless, debates about legal regulations, together with discussions of politics, provided a wide discursive site in which the modern Chinese meanings of same-sex relations were constructed. 


\section{Notes}

This essay derives from my dissertation. I would like to express my deepest gratitude to my advisors, Gail Hershatter, Emily Honig, and Lisa Rofel. I also want to thank Lisa Rofel and Petrus Liu for inviting me to contribute to the issue and spending their valuable time on this essay, and the two anonymous readers for their careful and encouraging comments.

I. Frank Dikötter, Sex, Culture and Modernity in China: Medical Science and the Construction of Sexualities in the Early Republican Period (Honolulu: University of Hawai'i Press, I995), I 45 .

2. Tze-lan D. Sang, The Emerging Lesbian: Female Same-Sex Desire in Modern China (Chicago: University of Chicago Press, 2003), Ioo.

3. Eve K. Sedgwick, Epistemology of the Closet (Berkeley: University of California Press, I990), I.

4. Ibid., I-2.

5. It should be made clear up front that this term, "pi," has broad application and does not apply exclusively to male same-sex relations. The same is true of the term "renyao." See my following discussion.

6. Judith T. Zeitlin, Historians of the Strange: Pu Songling and the Chinese Classical Tale (Stanford, CA: Stanford University Press, I993), 6r.

7. Ibid., 63 .

8. Ibid.

9. For a brief introduction to this writer, see the publisher's note in Yu Muxia, Shanghai linzhao (Shanghai: Shanghai Shudian Chubanshe, I998 [I933, I935]), I.

Io. For another example where the writer understood tongxinglian'ai as jijian, see the article “Tu’erye yu falü” (兔儿芧与法律, “Rabbits and Law”), Jingbao, March 30, I929.

II. For another example where the writer replaced mojing with tongxinglian'ai, see Wang Zhongxian, Shanghai suyu tushuo (Shanghai: Shanghai Shudian Chubanshe, I999 [I935]), I 49.

12. Yu, Shanghai linzhao, 25.

I3. Ibid.

I4. "Cultivated ladies” is Susan Mann's translation. See Susan Mann, Precious Records: Women in China's Long Eighteenth Century (Stanford, CA: Stanford University Press, 1997), 93.

I5. According to the Classical and Modern Chinese Dictionary (Gujin hanyu zidian), youwu could refer to a beautiful woman or a rare object. You itself could mean "outstanding." I translate youwu as "unique creature" to make the connection with the meaning of yao, as the Chinese idiom "wuyouzheyao," which means "when something is too outstanding, it becomes a freak," suggests.

I6. Tianfengbao, January 20, I932.

I7. Lydia Liu's translingual practice theory can also be applied here, but I am more interested in the receptive discursive conditions. See Lydia Liu, Translingual Practice: Literature, National 
Culture, and Translated Modernity - China, 1900-1937 (Stanford, CA: Stanford University Press, 1995).

I8. Other cases of such relationships were those between high-ranking officials and Peking Opera actors.

19. See Zhang Zhenhe, "Cao Kun," in Minguo renwu zhuan (Biographies of People during the Republican Period) (Beijing: Zhonghua Shuju, 1978), I72-78 and Howard Boorman and Richard Howard, eds., Biographic Dictionary of Republican China (New York: Columbia University Press, I971), 302-5.

20. Tao Juyin, Zhenghai yiwen (Anecdotes of the Political Arena) (Shanghai: Shanghai Shudian, I998 [I934]): $45-46$.

21. Jingbao, January I5, 1924 .

22. This explanation is not necessarily accurate. In Cantonese, the word zai (崽) is written as another character (㖊), which means boys or children. The writer simply used his explanation to make his second point.

23. In the writings about female same-sex relations, conservative writers did not hesitate to use imported Western terms such as homosexuality (tongxinglian'ai) to draw a connection between the phenomenon and new Western thoughts in order to attack the New Culture advocates. In writings about the Cao-Li case, however, "homosexuality" was rarely used. For those writers, the emperor-male favorite model was sufficient to explain the Cao-Li relationship.

24. Jingbao, March 3 and 6, I924.

25. Jingbao, July 27 and August 3, I924. "Rabbit" is local slang referring to men who have sex with other men.

26. Jingbao, November 9, 1924 .

27. Jingbao, October 30, I924.

28. Jingbao, December 9, I924.

29. For the history of the puppet state Manchuria, see Louise Young, Japan's Total Empire: Manchuria and the Culture of Wartime Imperialism (Berkeley: University of California Press, 1998) and Prasenjit Duara, Sovereignty and Authenticity: Manchukuo and the East Asian Modern (Lanham, MD: Rowman \& Littlefield Publishers, 2003).

30. Jingbao, August 18, I931.

3I. Here, "was not favored" means the emperor did not have sexual intercourse with her. The expression "xing" is a special verb used to describe the emperor's choice of his concubines for the night in a euphemistic way. Correspondingly, a male favorite was called "ningxing."

32. Jingbao, September 3, I931.

33. Jingbao, January 2 I, I932.

34. See “Cut Sleeve (Duanxiu, 短袖) Rampant in the Puppet State," Jingbao, August 26, I933 and "Puyi Indulging in Alcohol and Sex," Tianfengbao, February I5, I933. 
35. A 1935 Crystal report said that two beautiful young men, each from a rich family, went to Puyi's court and became his personal bodyguards. One was newly married, but left his wife and came to the Northeast to take care of his family property. The other one had just divorced his wife. They were so rich that they did not mind taking a low position. The report clearly hinted that the relationship between Puyi and the two young guards was sexual. See Jingbao, August 13, 1935 .

36. Jingbao, August I8, 1925 .

37. Jingbao, January 31, I926.

38. See Philip C. Huang, Code, Custom and Legal Practice in China: The Qing and the Republic Compared (Stanford, CA: Stanford University Press, 200I), I8, 2 I.

39. Ibid., 2, I6, I8, I80.

40. Ibid., I63.

4I. Ibid., I66. The Chinese characters are added.

42. Ibid., I82.

43. Jingbao, August 27, 1925 .

44. I have not been able to locate the original writer of the work.

45. Wu referred to the criminal code used in the first twenty years after the fall of the Qing dynasty, the New Criminal Code Temporarily in Force (zanxingxinxinglü, 暂行新刑律), which was promulgated in I9I2. According to Philip Huang, "the criminal code was patterned after the new Japanese code, borrowed almost intact from German law." See Huang, Code, Custom and Legal Practice, I6. For a study of Qing law in Chinese, See Zhang Jinfan, ed., Qingchao fazhishi (The Legal History of the Qing Dynasty) (Beijing: Zhonghua Shuju, I998), $695-704$.

46. Wu illustrated his points by listing the articles of the criminal code (xingfa, 刑法): Those who conducted lewd act with a male or female younger than thirteen years old should be sentenced to third- to fifth-degree imprisonment or be fined from 30 to 300 yuan. Those who conducted lewd acts through force, threat, medicine, hypnotism, or other means that made the person unable to resist should be sentenced to second- to third-degree imprisonment or be fined from 50 to 500 yuan (Article 283). Those who conducted lewd acts with a male or female older than twelve old through force, threat, hypnotism, or other means that made the person unable to resist should be sentenced to third- to fifth-degree imprisonment or be fined from 30 to 300 yuan (Article 284). Those who conducted lewd acts or illicit sex (jianyin, 奸滛) with anyone who had lost consciousness or could not resist should be punished according to the second item of Article 283, as well as Article 284 and Article 285 (Article 286). In case death or injury occurred in the above four offenses, the sentence should be as follows: from first-degree imprisonment to life imprisonment to the death penalty for death or fatal injury (duji, 笃疾); from second-degree imprisonment to the death penalty for an incapacitating injury (feiji, 废疾). If the victim committed suicide out of humiliation or was 
injured due to an attempted suicide, the sentence should be the same as the previous article (Article 287). All civil rights will be revoked for those who are sentenced to second-degree imprisonment or above for the felonies listed in this chapter (Article 295).

47. Jingbao, January 31, 1926.

48. Jingbao, February 3, 1926.

49. The writer did not mention which time period this law was from.

50. Quoted in Matthew Sommer, Sex, Law and Society in Late Imperial China (Stanford, CA: Stanford University Press, 2000), I I9-20; the Chinese characters are added.

5I. Ibid., I20.

52. Ibid., I24.

53. Ibid., I25.

54. Ibid.

55. When looking for records on male same-sex relations in the Beijing Municipal Archive, I was told by a senior staffer that male same-sex relations were not criminalized during the Republican era, and therefore no records could be found in the archive.

56. Quoted in Zhang, Qingchao fazhishi, 699. 